\title{
PENGARUH PELATIHAN SMALL SIDED GAMES TERHADAP PENINGKATAN KAPASITAS AEROBIK MAKSIMAL DAN KETERAMPILAN DRIBBLING PADA PEMAIN SEPAKBOLA
}

\author{
RIZKI APRILIYANTO \\ FKIP Universitas Muhammadiyah Jember \\ rizkiapriliyanto@unmuhjember.ac.id
}

\begin{abstract}
ABSTRAK
Tujuan dari penelitian ini adalah untuk menguji pengaruh ukuran lapangan yang berbeda pada pelatihan small sided games. Ukuran lapangan besar (62 x $44 \mathrm{~m})$ dan ukuran lapagan kecil $(32 \times 23 \mathrm{~m})$. Tiga puluh pemain terlibat dalam penelitian ini dan terbagi menjadi tiga kelompok. Kelompok eksperimen I pelatihan small sided games ukuran lapangan besar. Kelompok eksperimen II pelatihan small sided games ukuran lapangan keci dan kelompok kontrol dengan pelatihan konvensional. Penilaian dari pelatihan small sided games diukur menggunakan dua macam test: a) multistage fitness test, b) test dribbling.Jenis penelitian ini adalah penelitian eksperimen dengan menggunakan Randomized Control Group Pretest-Posttest Design. Analisis MANOVA menunjukkan bahwa ukuran lapangan besar lebih optimal dibandingkan dengan ukuran lapangan kecil dan kelompok kontrol. Hasil penelitian menunjukkan bahwa ukuran lapangan adalah faktor yang lebih berpengaruh. Pengaruh dari faktor ukuran lapangan dapat menyebabakan beban kerja pemain. Dalam hal ini peningkatan kapasitas aerobik maksimal dan keterampilan dribbling.
\end{abstract}

Kata Kunci: kapasitas aerobik maksimal, keterampilan dribbling, small sided games, sepakbola

\section{PENDAHULUAN}

Sepakbola telah menyita perhatian masyarakat dunia.Banyaknya informasi sepakbola yang disajikan oleh media cetak dan elektronik menciptakan antusiasme. Ini berlaku bagi semua kalangan lintas usia, gender dan strata. Fenomena ini mencapai puncaknya ketika pada akhir pekan jutaan warga dunia melibatkan diri dalam sepakbola Berbagai tournament baik itu Piala Dunia, Piala Eropa maupun Piala Asia selalu menyajikan permainan yang atraktif dan menarik untuk ditonton dan selalu menghadirkan beberapa kandidat juara.Induk organisasi sepakbola berbagai negara terus berlomba membenahi diri untuk jadi yang terbaik.

Kondisi tersebut tentunya berpengaruh banyak kepada proses pembinaan dari sejak usia muda. Usaha PSSI menciptakan tim nasional senior yang tangguh menjadi 
percuma saat akar pembinaan usia muda rapuh. Mempersiapkan pemain yang berprestasi tidak dapat dilakukan secara "instan" atau mendadak. Maka komponen yang paling mendasar dan harus mendapat perhatian yang serius adalah pembinaan usia muda yang secara sistematis dan berkesinambungan.

Pembinaan pemain sepakbola di usia muda (13-20 tahun) sangatlah penting, karena ini merupakan pondasi untuk bisa berkompeten di level yang lebih tinggi. Pembinaan pemain tersebut tentunya membutuhkan proses yang cukup lama, baik dari segi program latihan yang terarah maupun usia saat mulai latihan. Untuk menjadi seorang pemain sepakbola yang baik, dimulai latihan pada usia 8 atau 10 tahun sedangkan usia puncak pencapaian prestasi pada usia 18-20 tahun (Herwin, 2006). Hal ini menunjukkan bahwa untuk mencapai prestasi puncak seorang pemain sepakbola perlu waktu kurang lebih 10 tahun latihan.

Sajoto (1995) mengungkapkan bahwa tercapainya prestasi dalam olahraga adalah usaha yang benar-benar cermat dengan melakukan pembinaan dan pembibitan secara dini melalui pendekatan ilmiah dengan ilmu-ilmu pengetahuan yang terkait.Dengan demikian upaya untuk mencetak pemain sepakbola yang berprestasi baik ditingkat nasional maupun internasional, harus didasarkan pada kaidah-kaidah ilmiah.

Kajian ilmu pengetahuan yang meliputi fisiologis, biomekanika, psikologi, tes dan pengukuran, kesehatan olahraga, belajar gerak, ilmu gizi, sejarah dan sosiologi adalah sub disiplin ilmu untuk menunjang teori dan metodologi pelatihan (Harsono, 1988). Disamping itu tercapainya pembinaan prestasi olahraga sepakbola dipengaruhi oleh faktor yang mendasar dalam pelatihan.Faktor yang dimaksud adalah persiapan fisik, teknik, taktik, psikologi, dan teori yang saling terkait dalam semua program atlet.Oleh karenanya faktor-faktor tersebut perlu diperhatikan bagi para pelatih.

Kemampuan fisik pada permainan sepakbola merupakan kemampuan dasar yang perlu dimiliki oleh pemain untuk menunjang kemampuan lainnya. Pemain akan lebih memiliki rasa percaya diri yang tinggi apabila memiliki kemampuan fisik yang prima. Kondisi fisik tidak dapat ditingkatkan dan dikembangkan hanya dalam waktu sesaat atau dalam beberapa pertemuan saja, melainkan perlu dilakukan dalam jangka waktu yang relatif lama.

Dengan demikian upaya untuk peningkatan kondisi fisik perlu dilakukan sejak usia muda, tergantung cabang olahraga yang dilakukan. Demikian pula dengan cabang olahraga sepakbola, perlu ditingkatkan dan dikembangkan sejak usia muda dengan memperhatikan proses pertumbuhan dan perkembangan motorik anak. Oleh karena itu takaran latihan harus 
tepat dengan menyesuaikan proses pertumbuhan. Dengan takaran yang tepat dan dimulai sejak usia muda, maka penguasaan kondisi fisik, serta komponen lainnya akan terpenuhi. Di samping itu, keterampilan teknik dasar olahraga sepakbola harus menjadi perhatian yang serius khususnya bagi pemain usia muda, karena ini merupakan fase awal pembentukan teknik dasar. Teknik dasar sepakbola merupakan salah satu elemen penting yang diberikan saat usia muda. Jika saat usia muda tidak terbentuk teknik dasar dengan baik maka kesalahan teknik itu akan permanen hingga dewasa. Oleh karena itu pelatih harus mengajarkan teknik dasar dengan benar, guna pencapaian prestasi dimasa mendatang. Ditinjau dari sisi fisiologis, kapasitas aerobik maksimal dianggap sebagai faktor yang mendukung dalam permainan sepakbola modern. Kapasitas aerobik para pemain sepakbola secara substansial berpengaruh terhadap kinerja teknis mereka dan pilihan taktis (Chamari, dkk, 2005).

Harus disadari bahwa proses pelatihan olahraga erat kaitanya dengan masalah efektifitas dan efisiensi pelaksanaan program latihan (Nasution, 2007). Metode latihan SSG (small sided games) dirasa memenuhi tuntutan tersebut, adanya unsur keterampilan teknik dan kemampuan kondisi fisik memenuhi secara spesifik serta penggunaan waktu akan mrnjadi efektif.Prinsip spesifikasi akan memberikan manfaat yang maksimal manakala rangsangan latihan mirip atau merupakan replikasi dari gerakan-gerakan yang dilakukan dalam olahraga sepakbola.

Hoff, dkk, (2002) mengungkapkan bahwa kehadiran bola selama small sided games memungkinkan peserta untuk meningkatkan kebugaran fisik serta keterampilan teknik dan taktik. Metode latihan SSG dirasa tepat bagi pemain usia muda, karena karakteristik latihan usia muda harus dimulai dari yang paling sederhana, dan mudah dilakukan sekaligus menyenangkan dengan unsur permainan.

\section{METODE PENELITIAN}

Metode penelitian ini adalah metode eksperimen. Eksperimen adalah suatu cara untuk mengungkapkan suatu hubungan antara dua variabel atau lebih dan juga untuk mencari pengaruh suatu variabel terhadap variabel lainya. Berdasarkan metode eksperimen tersebut, maka digunakan rancangan Randomized Control Group PretestPosttest Design.

\section{POPULASI DAN SAMPEL}

Populasi dalam penelitian ini adalah berjumlah tiga puluh orang yang mengikuti kegiatan ekstrakurikuler cabang olahraga sepakbola. Delapan orang ditambahkan sebagai penjaga gawang, namun tidak termasuk sampel dalam penelitian ini. Penjaga gawang ini diberikan agar tingkat kesulitan dalam mencetak gol bertambah dan 
seperti permainan sepakbola sebenarnya.

Mengacu pada desain diatas, maka populasi di atas akan dijadikan anggota sampel secara keseluruhan, dengan kata lain penelitian ini merupakan penelitian populasi. Randomisasi untuk mendapatkan ketiga kelompok tersebut dengan maksud memberikan kesempatan kepada semua objek populasi untuk memperoleh kesempatan yang sama. Hasil randomisasi dapat memudahkan untuk menentukan kelompok eksperimen dan kelompok kontrol.

\section{HASIL PENELITIAN}

\section{Kelompok Eksperimen I}

Perolehan data keterampilan dribbling yang menunjukkan adanya peningkatan menggirng bola setelah diberi perlakuan selama delapan minggu. Hal ini dapat dilihat dari rerata tes akhir sebesar 6,3610

yang lebih kecil dari rerata tes awal sebesar 7,5570.

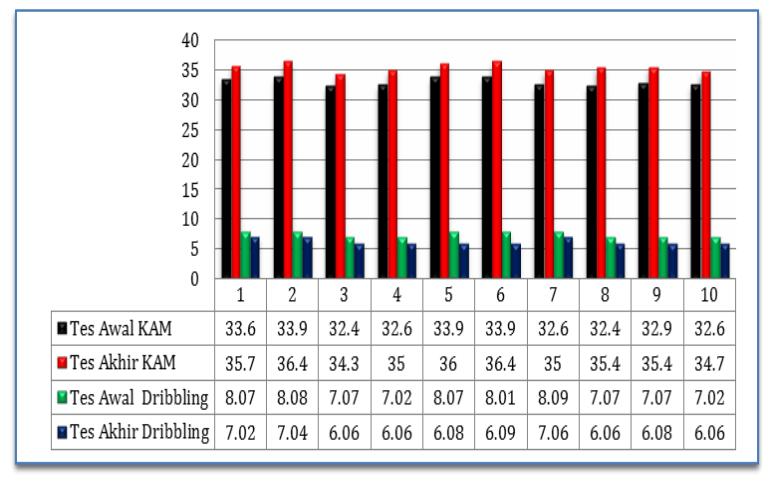

Hasil pada tabel tersebut diperoleh dari pengukuran kemampuan menggiring bola dengan mengadopsi tes keterampilan dribbling dari McGregor (dalam penelitian Katis dan Kellis 2009). Masing-masing peningkatan dari tes awal dan akhir dalam kelompok eksperimen I.

\section{Kelompok Eksperimen II}

Perolehan data kapasitas aerobik maksimal yang diperoleh dari hasil tes multistage fitness test, menunjukkan adanya penigkatan kapasitas aerobik maksimal setelah diberi perlakuan selama delapan minggu. Hal ini dapat dilihat dari rerata tes akhir sebesar 34,9700 yang lebih besar dari rerata tes awal sebesar 33,2800. Peningkatan akibat dari peningkatan dari pembebanan latihan dari durasi delapan menit sampai sepuluh menit selama delapan minggu dan dengan frekuensi pelatihan tiga kali dalam seminggu. 


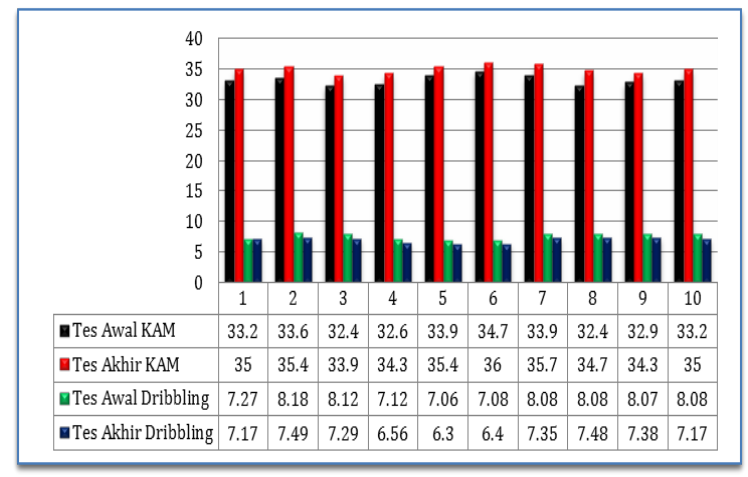

Keterampilan dribbling, menunjukkan peningkatan setelah diberi perlakuan. Hal ini dapat dilihat dari rerata tes akhir sebesar 7,0590 yang lebih kecil dari rerata tes awal sebesar 7,7140.

\section{Kelompok Kontrol}

Kelompok kontrol juga menunjukkan adanya penigkatan kapasitas aerobik maksimal. Hal ini dapat dilihat dari rerata tes akhir sebesar 33,7000 yang lebih besar dari rerata tes awal sebesar 33,2300. Demikian pula perolehan keterampilan dribbling yang diadopsi dari McGregor, dkk (dalam penelitian Katis dan Kellis 2009) juga memberikan peningkatan. Hal ini jika dilihat dari rerata tes akhir sebesar 7,3450 yang lebih kecil dari rerata tes awal sebesar 7,6190 menunjukkan peningkatan dalam kemampuan menggiring bola.

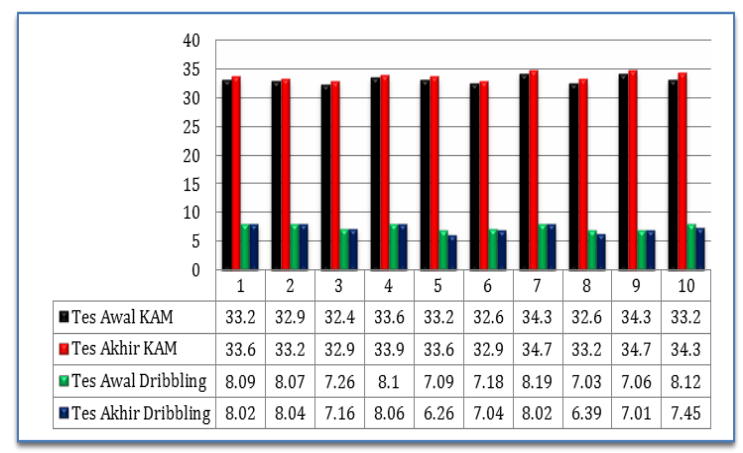

Dengan demikian kelompok kontrol juga memberikan dampak pada peningkatan kapasitas aerobik maksimal dan keterampilan dribbling, walaupun peningkatannya relatif kecil jika dibandingkan dengan kedua kelompok eksperimen sebelumnya.

\section{PEMBAHASAN}

Berdasarkan hasil penelitian yang sudah dilakukan bahwa pelatihan small sided 
games dapat meningkatkan kapasitas aerobik maksimal. Hal ini memperkuat pendapat Bondarev (2011) yang mengungkapkan bahwa pelatihan small sided games adalah sarana yang cocok untuk meningkatkan kardiovaskular. Lebih lanjut Hoff, dkk, (2002) menyatakan

bahwa kehadiran bola selama small sided games salah satunya dapat meningkatkan kebugaran fisik. Kedua pendapat diatas sejalan dengan hasil penelitian yang diilakukan oleh Casamichana \& Castellano (2010) yang menyatakan small sided games dengan format (5 vs 5) berguna untuk meningkatkan daya tahan aerobik pemain sepak bola muda. Demikian pula yang telah dilakukan oleh Dellal, dkk, (2011) yang juga meneliti pelatihan small sided games dengan format (2 vs 2) dan (3 vs 3) yang hasilnya dapat meningkatkan $\mathrm{VO}_{2}$ max pemain sepakbola usia muda.

Selain untuk mengkonfirmasi laporan yang ada, hasil ini menunjukkan bahwa small sided games dengan menggunakan ukuran lapangan yang berbeda terdapat perbedaan yang signifikan antara ukuran lapangan besar $(62$ x $44 \mathrm{~m})$ dengan lapangan kecil (32 x 23 m). Antara ukuran lapangan besar, lapangan kecil, dan pelatihan pada kelompok kontrol dari hasil analisis SPSS (statistical product and service solution) menunjukkan small sided games ukuran lapangan besar lebih baik dari small sided games ukuran lapangan kecil maupun pelatihan pada kelompok kontrol. Perbedaaan tersebut disebabkan oleh ukuran lapangan yang berbeda. Sebagaimana yang diungkapkan oleh Casamichana \& Castellano (2010) bahwa ukuran lapangan besar dapat meningkatkan beban kerja pemain. Sehingga dengan beban kerja yang lebih atau intensitas tinggi pada kelompok ukuran lapangan besar menyebabkan peningkatan lebih bagus dari ukuran lapangan kecil.

Sedangkan pada program pelatihan kelompok kontrol mengikuti program latihan sebagaimana mestinya, dalam hal ini program pada saat bersamaan dengan penelitian adalah finishing touch. Sehingga untuk peningkatan kapasitas aerobik maksimal ada peningkatan namun kecil sekali. Hal ini juga berlaku ketika small sided games ukuran lapangan kecil dibandingkan dengan pelatihan kelompok kontrol, yang mana hasil penelitian menunjukkan bahwa small sided games ukuran lapangan kecil lebih baik dari program pelatihan kelompok kontrol. Tampaknya program pelatihan small sided games di penelitian ini berguna untuk meningkatkan kapasitas aerobik maksimal pemain sepakbola muda. Dengan demikian dari beberapa format diatas dapat disimpulkan bahwa program pelatihan small sided games dengan format tersebut dapat meningkatkan kapasitas aerobik maksimal.

Pelatihan small sided games, juga dapat meningkatkan keterampilan dribbling. Hasil ini relevan dengan beberapa hasil penelitian yang dilakukan oleh penelitipeneliti sebelumnya, seperti Owen, dkk, (2004), mengungkap bahwa pelatihan small 
sided games dapat meningkatkan beberapa aspek salah satunya keterampilan teknik. Demikian pula Hoff, dkk, (2002) di mana dalam penelitiannya telah membuktikan salah satu dampak pelatihan small sided games, yakni dapat meningkatkan keterampilan teknik. Akan tetapi, disisi lain hasil penelitian ini tidak relevan dengan hasil penelitian yang dilakukan oleh Katis \& Kellis (2009), oleh karena dalam hasil penelitiannya, ternyata bentuk pelatihan small sided games (3 vs 3) dan (6 vs 6 ) tidak menunjukkan hasil yang signifikan terkait peningkatan terhadap keterampilan dribbling.

Hasil tersebut sangatlah wajar jika tidak relevan dengan hasil penelitian ini, oleh karena format yang digunakan berbeda dengan format pada penelitian ini (5 vs 5). Tidak konsistennya hasil penelitian ini dengan Katis \& Kellis (2009) sesuai dengan apa yang diutarakan oleh Dellal, dkk, (2011) yang menyatakan bahwa ketidakkonsistenan aturan dan format dalam small sided games

dapat menyebabkan hasil dan interpretasi yang berbeda.

Peningkatan keterampilan dribbling pada small sided games ukuran lapangan besar lebih optimal dari kelompok ukuran lapangan kecil maupun kelompok kontrol. Adanya perbedaan tersebut oleh karena ruang gerak pemain pada kelompok eksperimen I atau small sided games ukuran lapangan besar lebih luas dari kelompok eksperomen II atau small sided games ukuran lapangan kecil. Sehingga teknik dalam kelompok eksperimen I lebih sering dilakukan, tidak terkecuali keterampilan teknik dribbling. Sedangkan pada kelompok kontrol jika diuji dari teknik dasar mungkin yang lebih meningkat adalah keterampilan teknik shooting. Hal ini tidak terlepas dari program pada kelompok kontrol yang penekanannya pada pelatihan finishing touch.

\section{DAFTAR PUSTAKA}

Bompa, T.O, (1999). Perioddization, Theory and Methodology of Training $4^{\text {th }}$ Ed. Dubuque, IOWA: Kendall/Hunt Publishing Company.

Bompa, T.O, Haff, G.G, (2009). Perioddization, Theory and Methodology of Training $5^{\text {th }}$ Ed. Dubuque, IOWA: Kendall/Hunt Publishing Company.

Bloomfield, J., Polman, R., O'donoghue, P. (2007). Physical demands of different positions in FA Premier League soccer. Journal of Sports Science and Medicine $6,63-70$

Bondarev, D.V. (2011). Factors influencing cardiovascular responses during small sided soccer games performed with recreational purposes. Sevastopol National Technical University. 
Casamichana, D., \& Castellano, J. (2010). Time-motion, heart rate, perceptual and motor behaviour demands in small- sides soccer games: Effects of pitch size. Journal of Sports Sciences; 28(14): 1615-1623.

Chamari, K. Hachana, Y. F Kaouech, R Jeddi, I Moussa-Chamari, U Wisløff. (2005). Endurance training and testing with the ball in young elite soccer players. British Journal Sports Medicine, 39, 24-28

Coutts, A., \& Abt, G. (2005). Training aerobic capacity for improved performance in team sports. Australlian Sport Commissions. Vol 27 No 4.

David, R., Basset, J.R., \& Howley, E.T., (2000). Limiting factors for maximum oxygen uptake and determinants of endurance performance. American College of Sports Medicine.

Davies, P. (2005). Soccer Conditioning Total Soccer Fitness. Rio Network LLC. All Rights reserved worlwide.

Durandt J, Tee JC, Prim SK, \& Lambert MI. (2006) Physical fitness components associated with performance in a multiple-sprint test. Int J Sports Physiol Perf, 1(2): 150-60.

Herwin, (2006). Latihan Fisik Untuk Pemain Usia Muda. Jurnal Olahraga Prestasi Volume 2, Nomor 1, : $75-92$.

Hoff J, Wisløff U, Engen LC. (2002) Soccer specific aerobic endurance training. British Journal Sports Medicine;36:218-21.

Jones, S., \& Drust, B. (2007). Physiological and technical demands of $4 v 4$ and $8 v$

8 in eliteyouth soccer players. Kinesiology, 39, 150-156.

Katis, A. dan Kellis, E. (2009). Effects of small-sided games on physical conditioning and performance in young soccer players. Journal of Sports Science and Medicine. 8, 374-380.

Kelly, D., \& Drust, B. (2009). The effect of pitch dimensions on heart rate responses and technical demands of small-sided soccer games in elite players. Journal of Science and Medicine in Sport, 12, 475-479.

Owen, A., Twist C dan Ford, P. (2004). Small-Sided Games: The Physiological And Technical Effect Of Altering Pitch Size And Player Number. Insight-Issue 2, Volume 7.

Patlar, S., Mehtap, B., Bicer, M., Akil, M., Boyali, E., Celenk, C., \& Gunay, M. (2010). The effects of The game Form Training method (7v7 match) on Strength parameters of Soccer players. Bulletin of the Transilvania University of Braşov Vol. 3 (52)

Rampinini, E., Impellizzeri, F. M., Castagna, C., Abt, G., Chamari, K., Sassi, A. (2007). Factors influencing physiological responses to small-sided soccer 
games. Journal of Sports Sciences, 25, 659-666.

Reilly, T. (2005). Training Specificity for Soccer. International Journal of Applied Sports Sciences, Vol. 17, No. 2, 17-25.

Reilly, T., \& Gilbourne, D. (2003). Science and football: A review of applied research in the football codes. Journal of Sports Sciences, 21, 693 - 705.

Sajoto, M, (1995). Peningkatan Dan Pembinaan Kekuatan Kondisi Fisik dalam Olahraga. Semarang. Dahara Prize. Sarumpaet, A, (1992). Permainan Besar.

Semarang. Depdikbud.

Scheunemann, T. (2008). Dasar Sepakbola Modern, $2^{\text {th }}$ Ed. Malang. Dioma Publishing.

Scheunemann, T., Reyna, C., Perez, J., \& Gunadi, P. (2012). Kurikulum \& Pedoman Dasar Sepakbola Modern Untuk Usia Dini (U5-U12), Usia Muda (U13-U20) \& Senior. Jakarta : PSSI.

Silva, C.D., Blommfield, J., \& Marins, J.C.B. (2008). A review of stature, body mass and maximal oxygen uptake profiles of U17, U20 and first division players in Brazilian soccer. Journal of Sports Science and Medicine (2008) 7, 309-319.

Stephen, V., Hill, H., Greg, J.R., Dawson, B.T., \& Coutts, A.J. (2009). Acute physiological responses and time-Motion characteristics of two small-sided Training regimes in youth soccer players. Journal of Strength and Conditioning Research Vol 23 (1)/111- 115.

Sukadiyanto., \& Muluk, D. (2011). Pengantar Teori Dan Metodologi Melatih Fisik. Bandung: CV Lubuk Agung.

Sugiyanto. (1993). Belajar Gerak Bahan Panataran Pelatih Tingkat Dasar. Jakarta :Kantor Menpora.

Thompson, P.J.L. (1991). Introduction to Coaching Theory. Monaco. IAAF.

William, K., \& Owen, A. (2007). The Impact Of Player Numbers On the physiological Responses To Small Sided Games. Journal of Sports Science and Medicine. Suppl.10. 